\title{
Species Richness and Nutritive Values of Fodder and Their Relationship with Soil Characteristics in Ugandan Rangelands
}

\author{
Christine Kyoshabire ${ }^{1}$, Sarah Kizza ${ }^{2}$, Karumuna Rollanda ${ }^{3, *}$ \\ ${ }^{1}$ Ministry of Water and Environment, Department of Environment Affairs, Kampala, Uganda \\ ${ }^{2}$ Department of Engineering and Environment, Uganda Christian University, Mukono, Uganda \\ ${ }^{3}$ Health and Environment Research International (HERI), Kampala, Uganda
}

\section{Email address:}

karumunaroland@gmail.com (K. Rollanda)

*Corresponding author

\section{To cite this article:}

Christine Kyoshabire, Sarah Kizza, Karumuna Rollanda. Species Richness and Nutritive Values of Fodder and Their Relationship with Soil Characteristics in Ugandan Rangelands. American Journal of Agriculture and Forestry. Vol. 6, No. 3, 2018, pp. 38-43.

doi: 10.11648/j.ajaf.20180603.11

Received: July 18, 2017; Accepted: March 22, 2018; Published: May 18, 2018

\begin{abstract}
A study was conducted to determine the species richness and nutritive values of fodder and their relationship with soil characteristics in the Ugandan rangelands. The aim of the study was to determine the current status and nutritive values of fodder species and their relationship with soil characteristics. Four fodder species Panicum maximum - Guinea grass, Spartinaalterniflora - Cord grass, Hyperreniarufa -Jaragua/thatching grass and Acacia spp were selected for the study. The species were counted to determine their richness in their rangelands and also tested to establish their nutritive values. The focus on nutritive values was on $\mathrm{CP}, \mathrm{NDF}, \mathrm{Ca}, \mathrm{P}$ and $\mathrm{K}$. The research also determined the soil characteristics $\mathrm{pH}, \mathrm{OM}, \mathrm{N}, \mathrm{P}$ and $\mathrm{K}$. Results of the study show that the fodder species were below the recommended levels of species richness in the rangelands. Spartinaalterniflora (Cord grass) had the largest coverage of $109.1 \mathrm{Km}^{2}(22.4 \%)$ out of $486 \mathrm{Km}^{2}$ in the rangelands while Acacia had the lowest coverage of $10.2 \mathrm{Km}^{2}(2.1 \%)$. All the soil characteristics were below the minimum concertration levels apart from $\mathrm{P}$ and there was a significant difference in soil characteristics across the different locations $(\mathrm{P}<0.05)$. Average $\mathrm{pH}$ was 6.63 , OM was $0.5 \%$, and $\mathrm{P}$ was $74.09 \mathrm{ppm}$ while $\mathrm{K}$ was $17 \mathrm{cmoles} / \mathrm{kg}$. The most nutritious fodder species was Panicum maximum (Guinea grass). However all the fodder species were below the recommended nutrient levels. The mean concentration level of CP in all the fodder species was $8.95 \%$, Ca was $1.29 \%$, P was $0.4 \%$, K was $1.59 \%$ while NDF was $29 \%$. There was no significant difference in level of concentration across all the fodder species $(\mathrm{P}>0.05)$. Reduction of overstocking; growing of Panicum maximum (Guinea grass) at farm level; and rotation of animals are recommended.
\end{abstract}

Keywords: Rangeland, Fodder Species, Soil Characteristics, Species Richness

\section{Introduction}

Fodder species richness and their nutritive values has been a concern for most researchers focusing rangeland studies [1]. Their relationship with soil status has equally been a great concern due to the role played by soil through its soil characteristics [2]. The term rangeland globally refers to area with arid or semi-arid and dry sub-humid climates, and where topography and soils are unsuitable for food crop farming [3].

In the sub-Saharan region, rangelands have very limited opportunities for crop cultivation but are very suitable for livestock production. Most of these areas are dominated by arid and semi-arid landscapes [4]. Most rangeland dwellers prioritize cattle production over crop growing due to frequent droughts and low/fluctuating rainfall patterns.

In Uganda, as is the case in the rest of sub-Saharan Africa, naturally growing fodder still serve largely as a source of essential nutrients for livestock grazing. Species richness has potential to boost livestock productivity in rangelands. This is because the higher the richness the more balanced the nutritional values are for animal consumption in the rangelands [4]. In 
Uganda, species richness in the rangelands is not well studied, however the scanty information available shows that the fodder species in the rangelands are mainly Panicum maximum (Guinea grass), Spartinaalterniflora (Cord grass), Hyperreniarufa (Jaragua/thatching grass), and Acacia spp. [5-7]There are other species available in the rangelands but these are the dominant ones that support livestock grazing in the rangelands of Uganda.

The richness of fodder species and their nutritional values are among other factors influenced by physical and chemical properties of the soil in the rangelands. Soil types play a very big role in ensuring nutritional efficiency as well as richness in the rangelands [8]. Favourable soil characterises such as high organic matter and good $\mathrm{pH}$ are associated with high fodder regeneration rate in the rangelands. Similarly nutritional content in the fodder species is influenced by the soil characteristics such as nitrogen, phosphorous and potassium content in the soil. For example crude protein which is a critical ingredient in fodder species for livestock consumption is influenced by nitrogen content in the soil [3]. Concentrations of mineral elements in forage are dependent upon the interaction of a number of factors, including soil, plant species, stage of maturity, yield, pasture management and climate [9]. Even though it is a known fact that these factors influence nutritional efficiency of fodder species, little is known about the levels and extent of this in the rangelands of Uganda.

The rangeland conditions and status of fodder species has been largely attributed to unsustainable practices especially overgrazing, bush burning and deforestation that is largely influenced by charcoal trade [10]. Such practices lead to soil erosion and can hinder the net primary production of the grass layer yet soil nutrients and their accessibility are important factors controlling net primary productivity of rangeland's natural vegetation [7].

There has been little research done in rangeland areas of Uganda to determine species richness and nutritive values of fodder and their relationship with soil characteristics. Little information is available on the mineral status of the fodder species in rangelands of Uganda. It is not clear whether the fodder species available in rangelands for animals to graze on are still able to deliver the much needed nutrients to the animals; yet this information would be vital in planning the necessary improvements that would go a long way in improving the livelihoods of the people who depend on the rangelands for survival. This study thus investigated the current species richness, the soil characteristics and nutritive values of the fodder species (Panicum maximum (Guinea grass), Spartinaalterniflora (Cord grass), Hyperreniarufa (Jaragua/thatching grass), and Acacia spp.) in order to provide the right diagnosis to the problem identified above.

\section{Materials and Methods}

\subsection{Description of the Study Area}

The study was carried out in the rangelands of Kayunga District $74 \mathrm{Km}$ East of Kampala City in Uganda. Its coordinates are $1^{\circ} 20^{\prime} 41.0^{\prime \prime} \mathrm{N}, \quad 32^{\circ} 23^{\prime} 24.0^{\prime \prime} \mathrm{E}$ (Latitude:
1.2041N; Longitude: 32.8490). The altitude ranges between 1000-1200m above sea level. Kayonza sub-county occupies a land area of approximately $486 \mathrm{Km}^{2}$. Rural communities around the rangelands are mainly comprised of the Baganda, Basoga, Banyankole, Bagweri, Bakiga, Banyarwanda and immigrant Bahima among other ethnics. The precipitation, temperature, soil and vegetation in most of these areas support pastoralism activities which explain why agropastoralism is a popular practice in the rangelands of Uganda.

\subsection{Study Design}

Belt transects of up to $1 \mathrm{~km}$ between the $25 \mathrm{~m} \times 25 \mathrm{~m}$ demarcations to the north, south, east and west from the center of the selected parishes were established and divided into experimental plots (Kapu, 2012). At least 5 plots were established along each of the 4 directions making it a total of 20 plots per parish. The plots were 200 meters apart along the transects. A total of 40 plots were established for counting. There were however two plots at the centre where each of the two belt transects meet which were added to the 40 plots that were established in the two parishes making them 42 plots. The midpoints (centres) for the selected parishes were established through group discussions in which the local residents together with their leaders were engaged to draw resource maps. The actual counting was done by identifying the patches covered by each of the fodder species within the $25 \mathrm{~m} \times 25 \mathrm{~m}$ plots since grass cannot be counted individually. The width and lengths of the patches was then measured using a tape measure and recorded in the book. Plots were sketched and the patches located in each of the plots.

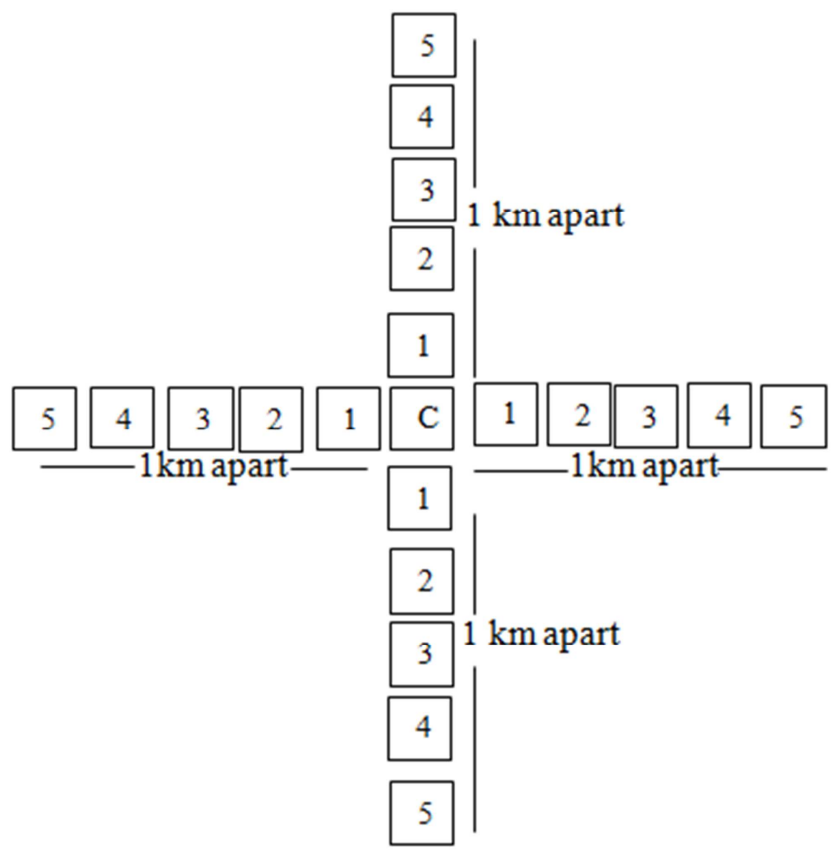

Figure 1. Distribution of the plots within the study area.

For soil sampling, two plots were randomly sampled along the west-east transects and the south-north transects for extracting soil samples. The sampling plot at the midpoint 
where the transects met/converged also acted as a sampling point [3]. In total 5 plots were randomly selected from each parish making it 10 plots from which soil was sampled. Soil samples were picked using an auger. Soil was picked from all the corners of the selected plots and mixed together before being packed in the polythene bags to achieve uniform distribution of soil. The soil was air dried under shade and the weather was sunny and windy. From each plot, at least $1 / 2$ a kilogram of soil was picked. Samples were marked and given labels according to the point of sampling before being transported to the laboratory for analysis to ease traceability problems. Soil was extracted between $0-20 \mathrm{~cm}$ deep from the surface using the soil auger. This was because the fodders sampled were shallow rooted.

Five tests were carried out on each sample making a total of 50 tests on the 10 soil samples collected. The tests covered $\mathrm{pH}$, Organic Mater Content (OM), Nitrogen (N), Phosphorus (P) and Potassium (K). Sample analysis was carried out following the procedures of Okalebo and Kapu [3, 11].

\subsection{Sampling of the Selected Fodder Species}

Five (5) plots were randomly selected from the 10 plots from where the soil was sampled. From each plot 4 fodder species (Panicum maximum - Guinea grass, Spartinaalterniflora - Cord grass, Hyperreniarufa Jaragua/thatching grass and Acacia spp) were sampled. Cutting was done at least $10 \mathrm{~cm}$ above the ground except for acacia which was harvested from the branches because the height of the acacia ranged between $0.5 \mathrm{~m}-2.5 \mathrm{~m}$. The grass was harvested with stems. The stems were targeted because of their richness in crude protein. Crude protein was among the parameters that were analyzed during the study. At least half a kilo of each fodder species was harvested. Twenty (20) samples were picked for analysis in the laboratory. Selected fodder species were put in clean paper bags. Samples were properly labelled to ease traceability in the laboratory. Samples were transported to the laboratory immediately to minimize changes in the physical and chemical integrity of the samples. Upon arrival at the laboratory, samples were checked for any damages, spoilage and deterioration before being accepted in the laboratory for analysis. All the procedures were guided by Kapu [3]. A total of 100 tests were carried out on the 20 samples. From each of the five plots, samples of the four species selected for the study were picked. This means that each species was sampled from each of the five plots. Each species was subjected to 5 tests. The tests were $\mathrm{CP}, \mathrm{NDF}, \mathrm{Ca}, \mathrm{P}$ and $\mathrm{K}$. Sample preparation and analysis was carried out following the procedures of VanSoest $[18,19]$

\subsection{Data Analysis}

Fodder species richness measured in each plot was calculated in meters and then converted to kilometres. Data from the laboratory about soil characteristics and nutrient content of fodder species was sorted in accordance with the codes assigned to the samples. Data was further segregated by species type and location. Analysis of variance and regression analysis were used to determine the significance of relationships between the samples and across the different locations. The correlation between soil characteristics and species richness was determined using a regression analysis in which $\mathrm{R}^{2}$ was determined.

\section{Results and Discussion}

\subsection{Coverage of Fodder Species}

The study showed that fodder species richness is generally low in the rangeland. Spartinaalterniflora (Cord grass)had the largest coverage of $109.1 \mathrm{~km}^{2}(22.4 \%)$ out of $486 \mathrm{Km}^{2}$ which Kayonza rangeland covers. Panicum maximum (Guinea grass) had the second largest coverage of $70.68 \mathrm{~km}^{2}$ (14.5\%) while Hyperreniarufa (Jaragua/thatching grass) covered $56.03 \mathrm{~km}^{2}(11.5 \%)$ of the three grass species studied. As for acacia, the coverage was $10.2 \mathrm{Km}^{2}(2.1 \%)$ and was the lowest (Figure 2). Species richness must be at least $200 \mathrm{~m}^{2}$ and above in a plot of $25 \mathrm{mx} 25 \mathrm{~m}$ in a savannah rangeland [3]. However, from the analysis of results, it was found out that the average richness of species in the plots that were randomly established during field data collection was $102.73 \mathrm{~m}^{2}$ per plot of $25 \mathrm{mx} 25 \mathrm{~m}$. This is below the recommended average. The low species richness points towards over grazing and conversion of some parts of the rangeland to crop lands. There was evidence of crop growing activity in some farmlands. Some areas were first cultivated and later abandoned to regenerate and form pasture. This kind of pasture differed from the one that was observed in areas where crop farming had not been carried out. Most of the acacia was harvested for fuel as it gives good charcoal and firewood and attracts customers and this explains the low richness of the specie in the area. Analysis of variance (ANOVA) showed that there was a significant difference between coverage of the fodder species studied $(\mathrm{P}<0.05)$.

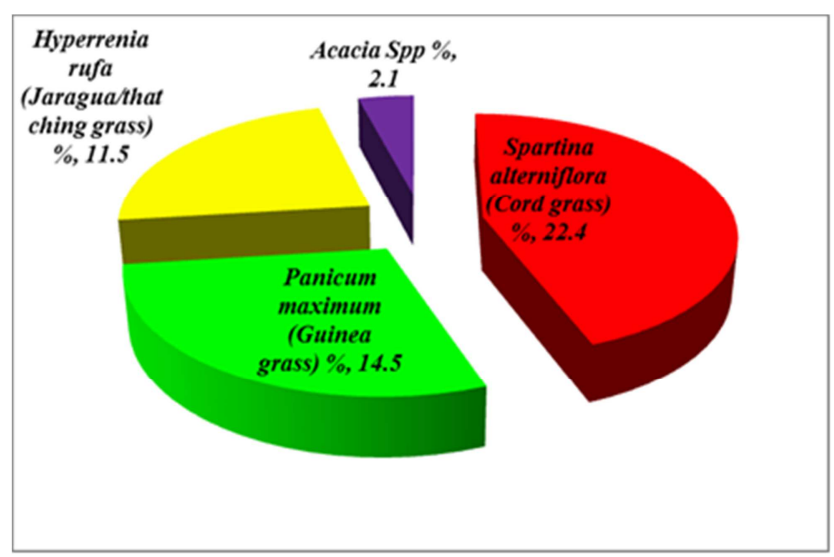

Figure 2. Coverage of fodder species in the rangeland.

Species richness also correlated with soil characteristics. Kapureported that soil conditions significantly influence the richness of grass in rangelands [3]. This is the case in Kayonzarangelands because the areas that had high level of 
species richness were also found to be more fertile. Overgrazing could also contribute to species reduction. During the study it was observed that areas which were not overgrazed had high species richness. This is a clear indication that overgrazing could negatively affect species richness. Related observations were made by Smet and Ward [12]. These report that plant species composition, diversity and vegetation structure in a semi-arid savannah is affected by the size of the herd per square kilometre in the rangeland.

\subsection{Physical and Chemical Properties of the Soil}

Soil was generally not suitable for growing fodder as evidenced from the results of status of $\mathrm{pH}$, Organic Matter $(\mathrm{OM})$, Nitrogen $(\mathrm{N})$ and Potassium $(\mathrm{K})$. Eighty percent $(80 \%)$ of the soil samples tested for OM content were below the recommended levels of $>3 \%$. Concerning $\mathrm{pH}$, only $40 \%$ of the samples were within the recommended levels of 5.5-6.5. As for $\mathrm{N}$, only one sample met the recommended level of $0.2 \%$. The rest of the samples $(90 \%)$ were below the recommended levels. Concerning K, none of the samples met the recommended level of concertration which is $>3 \mathrm{moles} / \mathrm{kg}$. However, all the soil samples met recommended levels of available $\mathrm{P}$. The average concentration of $\mathrm{pH}, \mathrm{OM}, \mathrm{N}, \mathrm{P}$ and $\mathrm{K}$ was $6.63,2.39 \%, 0.15 \%, 74.09 \mathrm{ppm}$ and $2.17 \mathrm{moles} / \mathrm{kg}$ respectively (Table 1). Soil whose average concentration of $\mathrm{OM}$ is above $3 \%$ with Nitrogen concentration that is above $0.2 \%$ is regarded to be suitable for animal fodder (3 and 15). This is because such soil will favour the quick growth and multiplication of the grass. Related results were obtained by Solomon, [13] during assessment of rangeland dynamics in southern Ethiopia in which focus was put on the botanical composition of grasses and soil characteristics in relation to land-use and distance from water. The study found out that the rangeland soils were fertile but lacked adequate moisture to facilitate the effectiveness of the chemical properties in the soil.

The physical and chemical properties of the soil varied greatly with different locations $(\mathrm{P}<0.05)$. This correlates with the fodder species richness where areas that had better soil properties also had high species richness. These variations could be attributed to overgrazing, over cultivation, variations in defoliation levels of vegetation cover in the rangeland and differences in moisture levels [3].

Table 1. Status of physical and chemical properties of the soil.

\begin{tabular}{lllll}
\hline $\mathbf{p H}$ & $\mathbf{O M}$ & $\mathbf{N}$ & Mean $\mathbf{P}$ & $\mathbf{K}$ \\
\cline { 2 - 5 } & \%age & & $\mathbf{p p m}(\mathbf{m g} / \mathbf{k g})$ & $\mathbf{c m o l e s} / \mathbf{k g}$ \\
\hline 6.39 & 2.94 & 0.19 & 49.2 & 2.20 \\
6.68 & 2.45 & 0.16 & 96.2 & 2.75 \\
6.58 & 3.24 & 0.20 & 62.3 & 2.26 \\
6.38 & 2.16 & 0.11 & 38.2 & 1.83 \\
6.90 & 1.96 & 0.10 & 102.3 & 2.36 \\
6.94 & 1.57 & 0.14 & 126.5 & 2.26 \\
7.14 & 1.67 & 0.10 & 130.4 & 2.56 \\
6.74 & 3.14 & 0.19 & 59.7 & 1.69 \\
6.45 & 2.45 & 0.15 & 36.4 & 1.77 \\
6.12 & 2.35 & 0.14 & 39.7 & $2.17 \mathrm{moles} / \mathrm{kg}$ \\
Mean & & & $74.09 \mathrm{ppm}$ & $>3 \mathrm{moles} / \mathrm{kg}$ \\
6.63 & $2.39 \%$ & $0.15 \%$ & $>15 \mathrm{ppm}$ & \\
Recommended levels & & & & \\
$5.5-6.5$ & $>3 \%$ & $>0.2 \%$ & &
\end{tabular}

The $\mathrm{pH}$ showed no significant difference between the different locations in the rangelands $(\mathrm{P}>0.05)$. The $\mathrm{pH}$ level is an important soil factor measured as level of acidity $(>6.5)$ or alkalinity $(<5.5)$. Incompliant soil $\mathrm{pH}$ can be a major contributing factor to fodder stand failure. The level of $\mathrm{pH}$ above 6.5 hinders available Phosphorus $(\mathrm{P})$ in soil for pasture uptake [3] and this was also true in the rangelands of Kayunga based on the regression analysis between $\mathrm{pH}$ and available $\mathrm{P}\left(\mathrm{R}^{2}=0.8167\right)$.

OM showed significant variations between different locations of the rangelands $(\mathrm{P}<0.05)$. $\mathrm{OM}$ was generally available across the rangelands probably due to the dense level of woody plants and grass defoliation [13] which accumulated a large portion of dead plants/grass material under a moist condition for rapid decaying and then these materials are converted into soil essential minerals [14]. There were significant variations between different locations of the rangelands as pertains to Nitrogen $(\mathrm{P}<0.05)$. The means of Nitrogen and Potassium at different locations were significantly different at an alpha of $0.05 . \mathrm{N}$ and $\mathrm{P}$ are essential nutrients for plant growth due to the large amounts absorbed from the root zone in the production of pastures [1]. At times $\mathrm{N}$ and $\mathrm{P}$ are unavailable because they are held between layers of clay mineral which is referred to as fixed Potassium [3]. The soils in the pasture lands studied lacked adequate amounts of $\mathrm{K}$ as evidenced by the results (Table 1). The concentration of $\mathrm{K}$ did not significantly differ in the different locations of the rangelands $(\mathrm{P}>0.05)$. However, in some pasture lands $\mathrm{K}$ is supplied in a recommended amount for nutrition of plants [1]. The variations in physical and chemical properties of the soil across different locations have also been reported by Maharjan [1] and past anthropogenic damage such as over cultivation, overgrazing, deforestation and bush burning (a common practice among the pastoralists) influence the variations.

The soil properties discussed above influenced species 
richness in the study area. This means that if the soil properties are favourable, there is a high potential for fodder to grow significantly [15]. However, if the soil properties are unfavourable, there is a likelihood of fodder species richness being low [13].

\subsection{Nutrient Composition of Fodder Species}

The analysis of results shows that majority of the nutritional values in the fodder species did not meet the recommended concentrations.

Table 2. Nutrient composition per fodder species.

\begin{tabular}{|c|c|c|c|c|c|}
\hline Sample Name & Phosphorus (P) \% & $\begin{array}{l}\text { Calcium } \\
(\mathrm{Ca}) \%\end{array}$ & $\begin{array}{l}\text { Potassium } \\
\text { (K) } \%\end{array}$ & $\begin{array}{l}\text { Neutral Detergent } \\
\text { Fibre (NDF) } \%\end{array}$ & $\begin{array}{l}\text { Crude } \\
\text { Protein \% } \\
\end{array}$ \\
\hline Panicum maximum (Guinea grass) & $0.33 \pm 0.2$ & $1.12 \pm 1.8$ & $1.92 \pm 0.43$ & $36.54 \pm 1.34$ & $11.56 \pm 0.24$ \\
\hline Spartinaalterniflora (Cordgrass) & $0.32 \pm 0.1$ & $1.3 \pm 1.4$ & $2.04 \pm 0.24$ & $30.2 \pm 0.8$ & $8.74 \pm 1.8$ \\
\hline Hyperreniarufa & $0.18 \pm 0.14$ & $1.1 \pm 0.42$ & $1.38 \pm 0.3$ & $23.2 \pm 0.38$ & $6.08 \pm 0.16$ \\
\hline Acacia spp & $0.52 \pm 0.32$ & $1 \pm 0.28$ & $0.98 \pm 0.24$ & $26.16 \pm 0.64$ & $9.4 \pm 1.5$ \\
\hline Recommended concentration & 0.6 & 1.4 & 2.2 & 39 & 14 \\
\hline
\end{tabular}

Panicum maximum (Guinea grass) had the highest percentage of $\mathrm{CP}(11.56 \pm 0.24 \%)$ while Hyperreniarufa (Jaragua/thatching grass) had the lowest percentage of CP $(6.08 \pm 0.16 \%)$. Ca was high in Hyperreniarufa (Jaragua/thatching grass) that is $1.34 \pm 1.4 \%$ and very law in Spartinaalterniflora (Cord grass). Acacia spp had the highest concertration of P $(0.52 \pm 0.32 \%)$, followed by Panicum maximum (Guinea grass) whose concertration was $0.33 \pm 0.2 \%$. $\mathrm{P}$ was very low in Hyperreniarufa (Jaragua/thatching grass) $-0.18 \pm 0.14 \%$. The species with the highest concentration of K $(2.04 \pm 0.24 \%)$ was Spartinaalterniflora (Cord grass). Acacia spp had the least concentration level of $0.98 \pm 0.24 \%$. Panicum maximum (Guinea grass) had the highest percentage of NDF $(36.54 \pm 1.34 \%)$. This was followed by Spartinaalterniflora (Cord grass) with NDF of $30.2 \pm 0.8 \%$. Hyperreniarufa (thatching grass) had the NDF percentage of $23.2 \pm 0.38 \%$. Acacia spp had the lowest percentage of NDF (26.16 $\pm 0.64 \%)$. Analysis of variance showed that there was no significant difference in nutrient composition across all the species $(\mathrm{P}<0.05)$. The concertration of nutrients in the fodder species varied with location and the soil characteristics. Areas that had high levels for $\mathrm{pH}, \mathrm{OM}, \mathrm{N}, \mathrm{P}$ and $\mathrm{K}$ had fodder species with high content of nutrients (Table 2). For example the higher the $\mathrm{N}$ the higher the level of $\mathrm{CP}$ that was found in the fodder species. The amino acids which are found in $\mathrm{CP}$ contain $\mathrm{N}$ which is a clear indicator that $\mathrm{N}$ levels have an influence on CP levels [16]. A correlation analysis was carried out to determine if the level of nutrients was related to soil characteristics. It was found out that indeed soil characteristics significantly influenced nutrient composition in fodder species $\left(\mathrm{R}^{2}=0.8126\right)$. Ca across all the species was significantly different $(\mathrm{P}<0.05)$. This means that the composition across all the species sampled for the study differed. However there were no variations in composition of $\mathrm{Ca}$ within the samples of the same species $(\mathrm{P}>0.05)$. Important to note was that Soil nutrient uptake status for the fodders studied was different. This further explains the variations in nutrient status of the fodder species studied. A related study by Kapu [3] also reports that Ca composition in fodder species found in rangelands significantly varied across all the species studied. This is because the level of $\mathrm{Ca}$ concertration in the soil directly impacts on how much $\mathrm{Ca}$ the plant will take in. Grass samples whose $\mathrm{P}$ was high had a correlation $\left(\mathrm{R}^{2}=0.6748\right)$ with the soil samples whose characteristics especially $\mathrm{pH}, \mathrm{OM}$ and $\mathrm{P}$ were high. This shows that soil characteristics influence the level of $\mathrm{P}$ in the fodder species. Well-structured soils have many pores and spaces in the soil to allow good drainage, easy plant root growth and efficient uptake of several nutrients including P. Soils which are rich in OM are more likely to have high concertration of $\mathrm{P}$ [17]. $\mathrm{K}$ is also an essential nutrient for plant growth and large amounts are absorbed from the root zone in the production of most fodder and it is classified as a macronutrient responsible for biochemical reaction in plants. It is as well being associated with movement of water, nutrients, and carbohydrates from one part of the plant to another as well as the opening and the closing of the stomata during the period of photosynthesis. If $\mathrm{K}$ is deficient or not supplied in adequate amounts, growth of pasture is stunted and yields are reduced. There was a significant difference between the species in the percentage of NDF $(\mathrm{P}<0.05)$. The $\mathrm{NDF} \%$ of a feed is that portion referred to as the cell wall fraction which can be digested by the animal. This cell wall is correlated to those indigestible fractions of the feed (cellulose, hemicelluloses and lignin) - [3, 14].

\section{Conclusion}

The richness of the fodder species studied was low and most of the soil samples did not meet the recommended levels and concertration of $\mathrm{pH}, \mathrm{OM}, \mathrm{N}, \mathrm{P}$ and K. Similarly most of the fodder species did not meet the recommended levels of nutrients. Spartinaalterniflora (Cord grass)was the most abundant fodder specie in in the rangeland. The most commonly consumed species in the rangelands was Spartinaalterniflora (Cord grass)probably due to its richness over the rest. Panicum maximum (Guinea grass) and Hyperreniarufa (Jaragua/thatching grass) though highly nutritious, were scarce. The scarcest of the fodders was Acacia spp. Species richness varied with location. In addition, the nutrient levels of the fodder species varied with location and soil physical and chemical characteristics. Locations with good soil characteristics had high species richness. This means that soil characteristics influence species richness. Highly grazed areas had lesser species richness which 
suggests that environmental degradation played a big role in species richness. The study recommends introduction of resting periods for some over grazed parts of the rangeland. Quick growing species such as Panicum maximum (Guinea grass) are encouraged to supplement the abundant species such as Spartinaalterniflora (Cord grass) which is less nutritious but highly grazed by the cows. Panicum maximum (Guinea grass) should be used for cattle feeding due to its nutrient efficiency over the rest of the fodder species.

\section{References}

[1] M. Maharjan, "Soil Carbon and Nutrient status of rangeland in upper Mustang," Institute of Forestry Pokhara, Nepal, Tribhuvan University, A Thesis Submitted in Partial Fulfillment of the Requirements for the Degree of Master of Science in Watershed Management, 2010.

[2] N. O. J. Abel, and P. M Blaikie, "Land degradation, stocking rates and conservation policies in the communal rangelands of Botswana and Zimbabwe". Land Degradation \& Development, Vol. 1, No.2, 2006, 101-123.

[3] N. L. Kapu, "Assessment of Rangeland Condition and Evaluation of the Nutritional Value of Common Grass and Browse Species at the Neudamm Experimental Farm, Namibia". MSc. Thesis University of Namibia, 2012

[4] A. Egeru, O. Wasonga, J. Mburu, E. Yazan, M. G. Majaliwa, L. MacOpiyo and Y. Bamutaze,"Drivers of forage availability: An integration of remote sensing and traditional ecological knowledge in Karamoja sub-region," Uganda. Pastoralism, Vol. 5, No. 20151, 1-18.

[5] P. J. Skerman and F. Riveros, "Tropical Grasses. FAO Publications", $1990 . \quad$ Available: http://www.fao.org/ag/AGP/AGPC/doc/Gbase/Data/Pf000259 .htm (Accessed: May 20, 2016).

[6] Food Agricultural Organisation (FAO), "Panicum maximum, guinea grass, colonial grass, Tanganyika grass," 2003, http://www.fao.org/ag/aga/agap/frg/AFRIS/DATA/11 8.HTM.

[7] A. D. Inselman, "Environmental degradation and conflict in Karamoja, Uganda: the decline of a pastoral society. International Journal of Global Environmental Issues Issue: Vol. 3, No. 2, 2003, $168-187$

[8] S. A. Nalule, "Social management of rangelands and settlement in Karamoja." Faculty of Veterinary Medicine, Makerere University, Kampala - Uganda, 2010 in Eilu, G., Hafashimana, D. L. N., \&Kasenene, J. M., 2004. Density and species diversity of trees in four tropical forests of the
Albertine rift, western Uganda. Diversity and Distributions 10 , 303312.

[9] E. M. Kennedy, J. P. McEvoy and O. M. Murphy, "Effect of restricted access time to pasture on dairy cow milk production, grazing behaviour, and dry matter intake". 2013, 169-179.

[10] A. Nimusiima, C. P. K. Basalirwa, J. G. M Majaliwa, W, Otim-Nape, J. Okello-Onen, C Rubaire-Akiiki, Konde-Lule. J and S Ogwal-Byenek, "Nature and dynamics of climate variability in the Uganda cattle corridor." African Journal of Environmental Science and Technology, Vol. 7, No. 8, 2013, 770-782.

[11] J. R. Okalebo, K. W. Gathua and P. L. Woomer, "Laboratory methods of soil and plant analysis: A working manual, 2nd Edition. TSBF-CIAT and SACRED Africa, Nairobi, Kenya, 1992.

[12] M. Smet, and D. Ward, "A comparison of the effects of different rangeland management systems on plant species composition, diversity and vegetation structure in a semi-arid savanna." African Journal of Range and Forage Science. Vol. 22 No. 1, pp. 59-71.

[13] T. B. Solomon, "Rangeland dynamics in southern Ethiopia: Botanical composition of grasses and soil characteristics in relation to land-use and distance from water in semi-arid Borana rangelands". Journal of Environmental Management Vol. 85, 2007, 429-442

[14] I. C. Okoli, C. S. Ebere, M. C. Uchegbu, C. A. Udah and I. I. Ibeawuchi, "A survey of the diversity of plants utilized for small ruminant feeding in south-eastern Nigeria." Agriculture, Ecosystems and Environment Vol. 96, 2009, 147-154.

[15] G. Tilahun, "Soil fertility status as influenced by different land uses in Maybar areas of South Wello Zone, North Ethiopia." A Thesis Submitted to the Faculty of the Department of Plant Sciences, School of Graduate Studies Haramaya University, 2007.

[16] E. J. Mtengeti and A. Mhelela, Screening of potential indigenous browse species in semi-arid central Tanzania. A case of Gairo division. Livestock Research for Rural development Vol. 18, No. 9, 2006.

[17] NSW, "Soil management for dairy and beef cattle grazing," (NSW Agriculture, Grafton), 2004.

[18] P. J. Van Soest, "Nutritional ecology of the ruminant": Cornell University Press, 1990

[19] P. J. Van Soest, J. Robertson and B. Lewis,"Methods for dietary fiber, neutral detergent fiber, and nonstarch polysaccharides in relation to animal nutrition." Journal of Dairy Science, Vol. 74 No. 10, 1991 3583-3597. 